\title{
Pengembangan Kemampuan Teknologi Informasi untuk Perangkat Desa di Desa Sumerta Kelod
}

\author{
${ }^{1}$ I Gusti Ngurah Wikranta Arsa, ${ }^{2}$ I Made Mika Parwita, ${ }^{3}$ Christine Intan De Maria S.A, \\ ${ }^{4}$ Dewa Ayu Inten Mahaputri \\ ITB STIKOM Bali ${ }^{1,2}$ \\ *Email: arsa@stikom-bali.ac.id², mika_parwita@stikom-bali.ac.id², intananggal@gmail.com³ \\ mahaputri18@gmail.com ${ }^{4}$
}

\begin{abstract}
ABSTRAK
Desa Sumerta Kelod memiliki jumlah penduduk 20.879 jiwa pada tahun 2016. Tingginya jumlah penduduk membuat Desa Sumerta Kelod mengedepankan misi menciptakan pelayanan publik dan mewujudkan pemerintah desa yang baik. Namun, desa ini masih memiliki beberapa masalah seperti kurangnya kemampuan para perangkat desa dalam penggunaan aplikasi komputer perkantoran seperti Microsoft Office yang dapat menunjang kinerja pelayanan publik seperti pembuatan surat ijin tinggal, berkas kependudukan, dan perhitungan anggaran desa. Permasalahan lainnya adalah kurangnya penggunaan dan pengelolaan konten sosial media atau website yang memberikan informasi kegiatan desa dalam menunjang misi transparansi dan akuntabilitas kegiatan dari desa. Target dari pengabdian ini adalah $80 \%$ perangkat desa Sumerta Kelod dapat mengoperasikan Microsoft Word dan Excel, menghasilkan modul workshop, serta dapat membuat konten website. Metode yang digunakan dalam pengabdian ini adalah mengadakan workshop Microsoft Office, penggunaan dan pembuatan konten website dan sosial media, serta evaluasi dari hasil kegiatan. Hasil kegiatan adalah dua buah modul workshop yaitu modul Microsoft Word dan Excel serta kegiatan workshop Microsoft Word tentang pembuatan daftar isi otomatis menggunakan multilevel list dan style serta Microsoft Excel dengan fungsi Vlookup. Hasil dari pelatihan pengelolaan website adalah konten yang telah terisi pada website yang bisa diakses pada website resmi Desa Sumerta Kelod. Berdasarkan hasil survey pretest dan postest pelatihan Microsoft Word dan Excel diperoleh peningkatan rata-rata jumlah peserta yang bisa dari $43,5 \%$ menjadi $85,8 \%$ dan penurunan yang tidak bisa dari $56,5 \%$ menjadi $14,2 \%$.
\end{abstract}

Kata kunci : konten website, Microsoft Office

\section{ABSTRACT}

Sumerta Kelod Village had a population of 20,879 inhabitants in 2016. With a high population, Sumerta Kelod Village put forward the mission of creating good public services and realizing good village government. However, Sumerta Kelod Village still has some problems, such as the lack of capacity of village officials in using office computer applications such as Microsoft Office, where these applications can support the performance of public services such as making residence permits, population documents, and calculating village budgets. Another problem is the lack of use and management of social media content or websites in providing information on village activities in 
supporting the mission of transparency and accountability of activities from the village. The target of this service is that $80 \%$ of the village staff of Sumerta Kelod can work on Microsoft Word and Excel projects, produce workshop modules, and village officials can create content on the website. The method used in this service is to hold Microsoft Office workshops, use and create website content and social media. Then an evaluation of the results of the activities is then carried out. The results of the activity were produced by two workshop modules namely Microsoft Word and Excel modules as well as Microsoft Word workshop activities on creating automatic table of contents using multilevel lists and styles as well as Microsoft Excel with the Vlookup function. The results of the website management training are content that has been filled on the website that can be accessed on the official website of Sumerta Kelod Village. From the results of the pretest and posttest survey of Microsoft Word and Excel training, the average increase in the number of participants could be from $43.5 \%$ to $85.8 \%$ and the decline that could not be from $56.5 \%$ to $14.2 \%$.

Key words: website content, microsoft office.

\section{PENDAHULUAN}

Desa Sumerta Kelod terletak di Kecamatan Denpasar Timur, Kotamadya Denpasar, Provinsi Bali, Indonesia. Data pada tahun 2016 menunjukkan desa ini memiliki penduduk dengan jumlah 20.879 jiwa menurut Badan Pusat Statistik Kota Denpasar dalam buku Kecamatan Denpasar Timur (Anonim, 2017). Desa Sumerta Kelod memiliki visi terwujudnya Desa Sumerta Kelod yang aman, tentram dan sejahtera melalui kearifan budaya berlandaskan Tri Hita Karana. Adapun misi Desa Sumerta Kelod adalah mewujudkan desa yang aman, nyaman dan berpendidikan, guna membentuk masyarakat cerdas dan sehat; menumbuhkembangkan kreatifitas masyarakat desa yang berbudaya; mewujudkan pemerintah desa yang baik dan berdedikasi; menciptakan pelayanan publik yang baik dan transparan; mempercepat pertumbuhan dan memperkuat ketahanan ekonomi melalui sistem kerakyatan; meningkatkan sinergi transformasi informasi, komunikasi serta koordinasi dalam implementasi pelaksanaan program kegiatan desa.
Dalam rangka mewujudkan misi menciptakan pelayanan publik yang baik serta mewujudkan pemerintah desa yang baik, Desa Sumerta Kelod masih memiliki beberapa masalah yang ditemui yaitu kemampuan para perangkat desa yang masih kurang dalam hal penggunaan aplikasi komputer perkantoran seperti Microsoft Office, padahal penggunaan aplikasi perkantoran (office) dapat menunjang kinerja pelayanan publik di Desa Sumerta Kelod seperti pembuatan surat ijin tinggal, berkas kependudukan, perhitungan anggaran desa dan lainnya. Berdasarkan diskusi dengan Sekretaris Desa Sumerta Kelod, mereka memerlukan pelatihan office untuk meningkatkan kemampuan para staf. Program yang sama juga pernah dilakukan oleh (Niati et al., 2019) dengan hasil Kegiatan Pengabdian Kepada Masyarakat melalui pelatihan dalam mengoperasionalkan komputer khususnya perangkat desa Mranggen maka dapat menambah wawasan dan pengetahuan serta meningkatkan kinerja perangkat desa secara lebih maksimal dalam memberikan layanan kepada masyarakat sesuai yang diinginkan pemerintah. Peningkatan kemampuan 
perangkat desa juga terjadi dengan adanya pengabdian masyarakat sesuai dengan yang dilakukan oleh (Sormin et al., 2018). Selain itu beberapa pengabdian masyarakat tentang pelatihan office dapat menghasilkan template laporan, template struktur organisasi dan template office lainnya yang dibutuhkan instansi (Haryoko and Wicaksono, 2018).

Permasalahan lain muncul dalam pemenuhan misi Desa Sumerta Kelod dalam hal menciptakan pelayanan publik yang baik dan transparan; meningkatkan sinergi transformasi informasi, komunikasi akuntabilitas yang mana hal ini terkait erat dengan instrumen untuk kegiatan kontrol terutama dalam hal pencapaian hasil pada pelayanan publik dan menyampaikannya secara transparan kepada masyarakat. Akuntabilitas berhubungan dengan pertanggungjawaban terhadap masyarakat melalui akses informasi dan keterbukaan (Hermansyah et al., 2018) serta koordinasi dalam implementasi pelaksanaan program kegiatan di desa. Saat ini Desa Sumerta Kelod telah memiliki website yang merupakan subdomain dari pemerintah kota Denpasar dan halaman Facebook. Namun belum ada publikasi yang memadai mengenai program kerja, aktifitas, anggaran, dan semua kegiatan dari Desa Sumerta Kelod. Informasi yang didapat mengenai Desa Sumerta Kelod dalam situs website yang dimiliki sangat minim dan disajikan dengan data yang kurang baik. Kemudian dari hasil penjelajahan akun sosial media, Desa Sumerta Kelod telah memiliki halaman Facebook, namun informasi mengenai kegiatan dan foto-foto kegiatan masih belum ditemukan. Berdasarkan hasil wawancara dengan Sekretaris Desa, memang sosial media yang dimiliki desa belum dikelola dengan baik karena kurangnya tenaga IT untuk pengelolaan sosial media.

Penggunaan sosial media membantu pelayanan publik menjadi lebih efisien seperti penelitian yang dilakukan oleh (Munandar dan Suherman, 2016). Selain itu, penggunaan media sosial pada pemerintahan adalah untuk membangun sistem pemerintahan yang terbuka dan transparan dengan menampung aspirasi dari masyarakatnya (Suryadharma dan Susanto, 2017). Saat ini media sosial merupakan media komunikasi yang efektif, tranparasi dan efisien serta memiliki peran penting sebagai agen perubahan dan pembaharuan. Penggunaan media sosial sebagai jembatan untuk membantu proses peralihan masyarakat yang tradisional ke masyarakat yang modern, khususnya untuk mentransfer informasi pembangunan yang dilaksanakan pemerintah kepada masyarakatnya (Rahadi, 2017).

\section{RUMUSAN MASALAH}

Berdasarkan hasil observasi dan diskusi dengan Kepala Desa Sumerta Kelod, adapun rumusan masalah pada pengabdian ini adalah: a) bagaimana meningkatkan pengetahuan mengenai penggunaan aplikasi perkantoran seperti Microsoft Word dan Excel bagi perangkat desa? b) bagaimana cara memaksimalkan penggunaan website dalam memberikan informasi kegiatan desa? dan c) bagaimana memaksimalkan pengelolaan konten website desa oleh perangkat desa?

\section{METODE}

Pengabdian ini merencanakan beberapa kegiatan untuk menunjang penyelesaian masalah yang telah dirumuskan sebelumnya. Adapun alur 
kegiatan yang diterapkan ditampilkan pada Gambar 1.

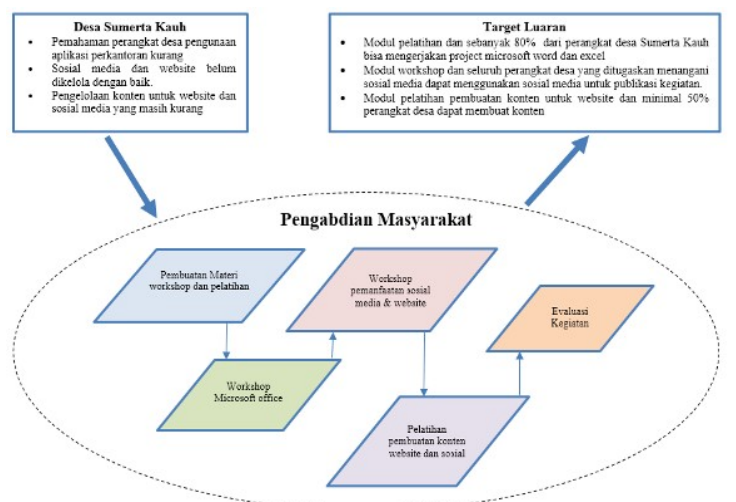

Gambar 1. Alur kegiatan pengabdian.

Metode yang digunakan untuk merealisasikan berbagai kegiatan tersebut adalah pendidikan masyarakat: kegiatan ini mencakup pengenalan dan pemahaman mengenai manfaat aplikasi perkantoran Microsoft Word dan Excel dalam menunjang kegiatan perkantoran desa. Kegiatan ini ditujukan untuk perangkat Desa Sumerta Kelod agar kinerja perkantoran lebih maksimal. Selain itu, diadakan juga sosialisasi mengenai manfaat dan pentingnya sosial media dalam pengembangan desa.

\section{Teknik Pengumpulan Data}

Data yang diperoleh untuk menunjang pengabdian ini berasal dari berbagai sumber. Di antaranya melalui observasi dan wawancara langsung ke Kantor Desa Sumerta Kelod di mana dilakukan wawancara dengan staf IT kantor desa, Sekretaris Desa dan Kepala Desa Sumerta Kelod. Selain itu, data juga dikumpulkan melalui beberapa literatur yang terkait dengan kegiatan ini.

\section{Analisis Situasi}

Analisis situasi perlu dilakukan untuk mengenal kondisi dan menggali potensi desa maupun aparat desa. Berdasarkan analisi situasi, diperoleh pandangan bahwa aspek aparat desa yang bisa dimaksimalkan untuk menunjang pelayanan desa, salah satunya adalah meningkatkan pelayanan dengan memanfaatkan aplikasi perkantoran dalam pembuatan dokumen-dokumen desa. Selain itu, hubungan sosial antara aparat desa dan masyarakat juga bisa dipererat melalui pembaruan informasi terkait kegiatan-kegiatan yang dilakukan aparat desa melalui media sosial yang dimiliki desa.

\section{Lokasi dan waktu}

Kegiatan yang diadakan berlokasi di Kantor Desa Sumerta Kelod, Kecamatan Denpasar Timur, Kotamadya Denpasar. Waktu pelaksanaan kegiatan pada tanggal 2 Februari 2020 untuk workshop office dan sosialisasi pemanfaatan sosial media. Selanjutnya kegiatan workshop pembuatan konten website dilakukan pada 11 Juni 2020 .

\section{PEMBAHASAN}

Kegiatan awal yang dilakukan dalam pengabdian ini adalah observasi mengenai aspek yang kurang maksimal ataupun yang dapat ditingkatkan dari pelayanan desa Sumerta Kelod. Kegiatan ini dilakukan langsung ke Kantor Desa Sumerta Kelod dan menghasilkan kesepakatan untuk melakukan workshop Office serta sosialisasi penggunaan dan pengembangan konten website Desa Sumerta Kelod. Kegiatan ini ditampilkan pada Gambar 2. 


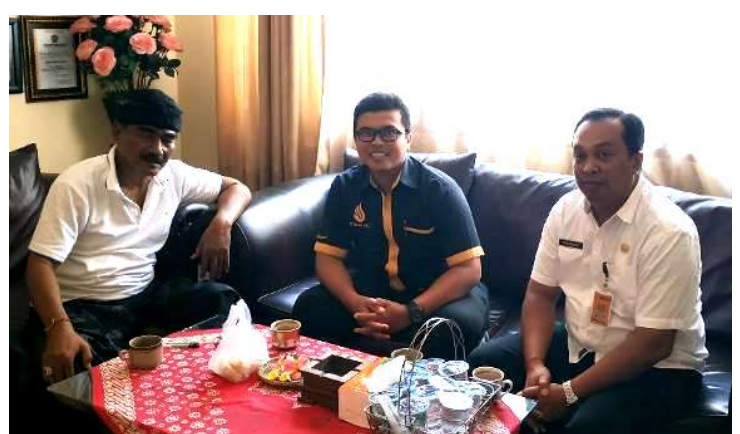

Gambar 2. Observasi ke Kantor Desa Sumerta Kelod

Kegiatan workshop Office dan sosialisasi sosial media dan website dilakukan di ruang pertemuan Kantor Desa Sumerta Kelod. Workshop Office diadakan pada tanggal 2 Februari 2020. Kegiatan dibuka oleh Sekretaris Desa dan foto bersama ditampilkan pada Gambar 3.

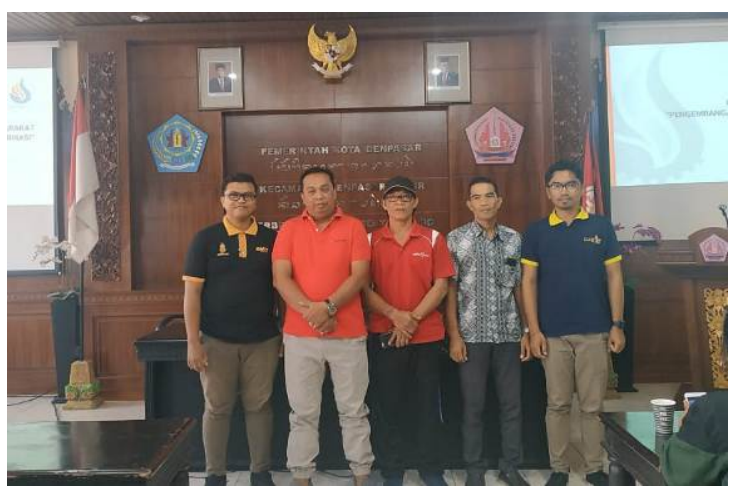

Gambar 3. Foto bersama aparat desa.
Peserta kegiatan ini adalah beberapa aparat Desa Sumerta Kelod dan tambahan dari teruna teruni banjar se-Desa Sumerta Kelod. Peserta pelatihan dapat dilihat pada Gambar 4.

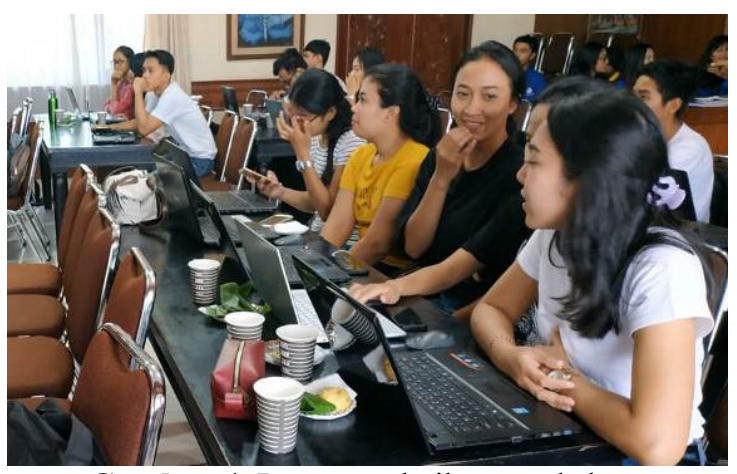

Gambar 4. Peserta pelatihan workshop.

Menindaklanjuti hasil kesepakatan dengan Sekretaris Desa, materi Office yang disampaikan dalam pelatihan adalah Microsoft Word dan Excel. Pemberian materi Office ditampilkan pada Gambar 5.

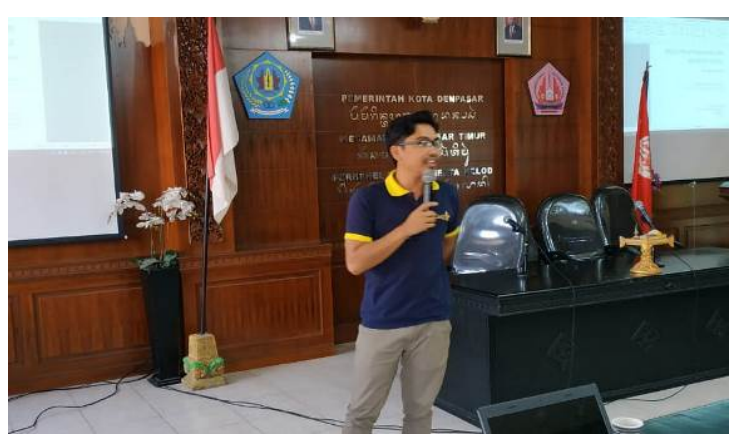

Gambar 5. Pemberian materi office.

Materi Microsoft Word mengenai pembuatan daftar isi otomatis dengan menggunakan multilevel list dan style ditampilkan pada Gambar 6. 

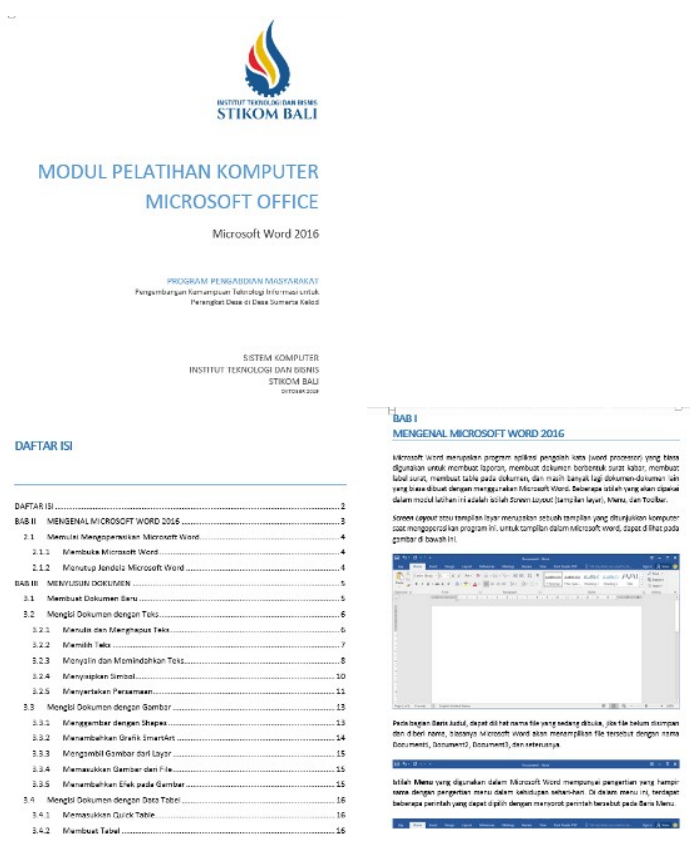

Gambar 6. Modul workshop Microsoft Word.

Materi Ms. Excel yang disepakati untuk dibahas mengenai Vlookup data yang ditampilkan pada Gambar 7.

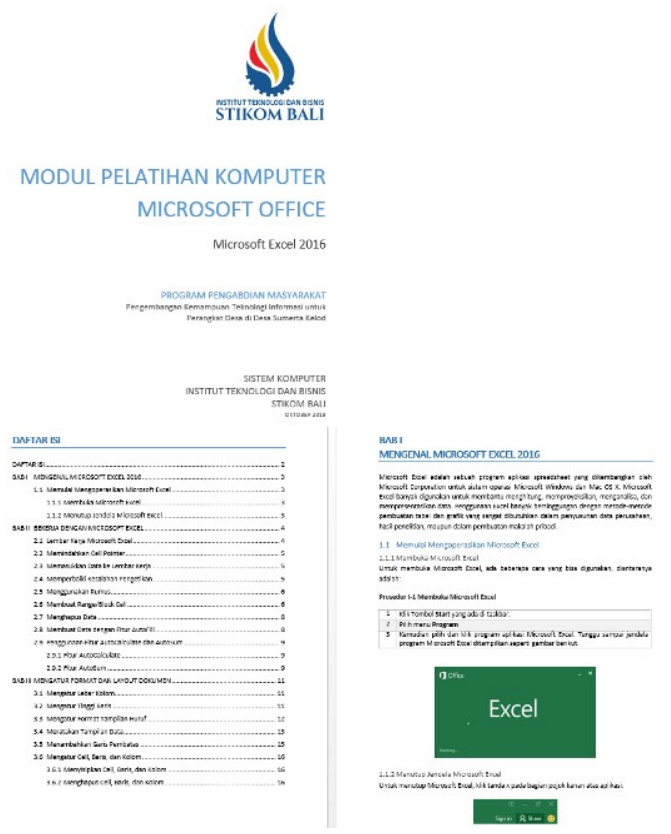

Gambar 7. Modul workshop Microsoft Excel.
Dalam kegiatan diberikan beberapa contoh kasus mengenai pembuatan daftar isi otomatis dan juga contoh penggunaan Vlookup pada Excel. Kegiatan workshop berlangsung selama kurang lebih 3 jam dimulai pada pukul 9 hingga pukul 12 siang. Materi daftar isi diambil berdasarkan kesepakatan dengan beberapa peserta dimana beberapa peserta meminta materi pembuatan daftar pustaka secara otomatis, karena beberapa materi seperti pembuatan surat sudah dipahami oleh peserta pelatihan. Dalam modul yang diberikan sudah berisi beberapa materi lainnya seperti pengenalan Microsoft Word, penyusunan dokumen, mengatur format dan layout, dan terakhir mengatur referensi. Sesuai dengan Gambar 6 . Namun peserta pada saat pelatihan memilih lebih terfokus dalam pembuatan daftar isi.

Untuk kegiatan pelatihan Ms. Excel pada modul berisikan tentang dasar dan formating pada Excel, namun pada pelatihan sesuai permintaan banyak meminta formula-formula dalam tabel sehingga banyak terfokus pada pelatihan penggunaan rumus seperti Vlookup, Hlookup, penghitungan rata-rata dan penentuan nilai tertinggi pada sebuah kolom.

Kegiatan sosialisasi sosial media dan website diadakan pada 11 Juni 2020. Pemberian materi sosial media dan website ditampilkan pada Gambar 8. Evaluasi kegiatan sosialisasi konten ini dilakukan dengan melihat isian pada konten portal desa sumerta kelod yang sudah mulai terisi khususnya bagian berita. Pada awal survei portal sumerta kelod beum terisi data samasekali dilakukan konfirmasi pada wawancara memang terkendala dengan petugas input dan kordinasi ke Pemkot Denpasar. Namun setelah dilakukan 
pelatihan konten maka mulai konten berita yang sudah mulai terisi. Seperti pada Gambar 9. Diperlukan pendampingan untuk pengisian konten serta karena terkendala petugas IT pada kantor Desa Sumerta Kelod perlu dibantu dengan sumber daya manusia yang pahan teknologi informasi sebagai penunjang kerja atau operator khusus memenejemen konten-konten portal ataupun sosial media. Untuk pelatihan sosial media hanya pengenalan bagaimana sosial media dapat dikelola sebagai media informasi Desa. Namun karena terkendala SDM pengelolaan sosial media belum terimplementasi dengan baik.

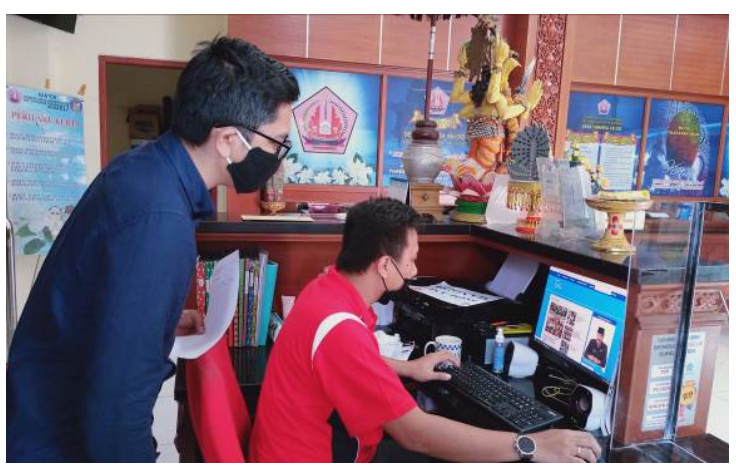

Gambar 8. Pemberian materi sosial media dan website.

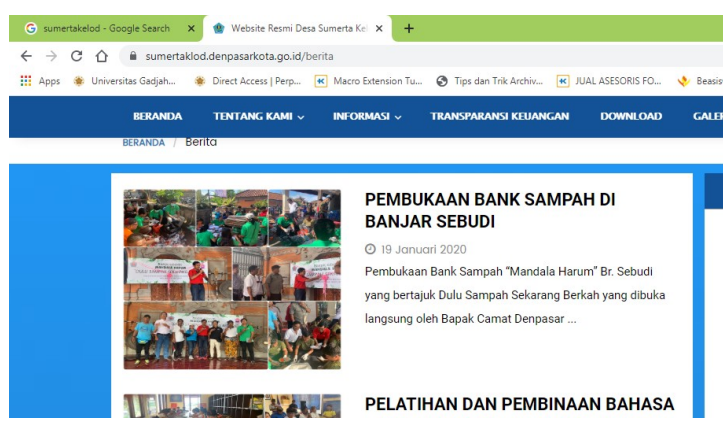

Gambar 9. Portal Desa Sumerta kelod menu berita

Evaluasi dari kegiatan dilakukan dengan melakukan survey pada sebelum (pre test) dan setelah semua kegiatan dilangsungkan (post test). Survey pada awal kegiatan dilakukan menggunakan google form dengan tujuan mengenai tingkat pemahaman para peserta mengenai materi yang akan disampaikan. Hasil survey ditampilkan pada Tabel 1 .

Tabel 1. Tabel hasil survey pemahaman materi.

\begin{tabular}{|c|c|c|c|c|c|}
\hline \multirow{2}{*}{ No } & \multirow{2}{*}{ Pertanyaan } & \multicolumn{2}{|c|}{ Pre test (\%) } & \multicolumn{2}{|c|}{ Post test (\%) } \\
\hline & & Bisa & Tidak & Bisa & Tidak \\
\hline 1 & $\begin{array}{l}\text { Apakah Anda } \\
\text { bisa membuat } \\
\text { daftar isi } \\
\text { otomatis } \\
\text { menggunakan } \\
\text { Ms. Word? }\end{array}$ & 34,8 & 65,2 & 80,3 & 19,7 \\
\hline 2 & $\begin{array}{l}\text { Apakah Anda } \\
\text { bisa } \\
\text { menggunakan } \\
\text { fungsi Style } \\
\text { pada Ms. } \\
\text { Word? } \\
\end{array}$ & 43,5 & 56,5 & 81 & 19 \\
\hline 3 & $\begin{array}{l}\text { Apakah Anda } \\
\text { bisa membuat } \\
\text { multilevel list } \\
\text { pada Ms. } \\
\text { Word? }\end{array}$ & 13 & 87 & 83,6 & 16,4 \\
\hline 4 & $\begin{array}{l}\text { Apakah Anda } \\
\text { bisa } \\
\text { menggunakan } \\
\text { rumus } \\
\text { aritmetika } \\
\text { dasar pada } \\
\text { Ms. Excel? }\end{array}$ & 65,2 & 34,8 & 92,4 & 7,6 \\
\hline 5 & $\begin{array}{l}\text { Apakah Anda } \\
\text { bisa } \\
\text { menggunakan } \\
\text { rumus SUM } \\
\text { pada } \quad \text { Ms. } \\
\text { Excel? }\end{array}$ & 65,2 & 34,8 & 95,1 & 4,9 \\
\hline 6 & $\begin{array}{l}\text { Apakah Anda } \\
\text { bisa } \\
\text { menggunakan } \\
\text { fungsi } \\
\text { LOOKUP } \\
\text { pada Ms. } \\
\text { Excel? } \\
\end{array}$ & 39,1 & 60,9 & 82,6 & 17,4 \\
\hline & Rata-rata & 43,5 & 56,5 & 85,8 & 14,2 \\
\hline
\end{tabular}

Survey kedua dilakukan di akhir kegiatan pemberian materi. Survey ini bertujuan untuk mengetahui tingkat pemahaman materi sekaligus mengetahui keberhasilan kegiatan ini. Hasil survey menunjukkan kegiatan workshop berjalan 
sesuai dengan yang diharapkan. Sebanyak $80 \%$ perangkat desa Sumerta Kelod dan peserta workshop dapat mengerjakan project Microsoft Word dan Excel sesuai dengan materi yang disampaikan. Hasil dari pengelolaan konten adalah konten yang sudah ditambahkan pada website resmi Desa Sumerta Kelod yang bisa diakses di https://sumertaklod.denpasarkota.go.id/.

\section{SIMPULAN}

Adapun simpulan dari kegiatan pengabdian masyarakat ini adalah:

1. Kegiatan pengabdian menghasilkan dua modul workshop Office yaitu modul Microsoft Word dan Excel yang membantu perangkat desa untuk lebih memahami tentang penggunaan kedua aplikasi perkantoran tersebut dalam meningkatkan kinerja perangkat desa.

2. Kegiatan workshop yang telah dilaksanakan membahas tentang pembuatan daftar isi otomatis menggunakan style dan multilevel list serta pada Excel membahas tentang fungsi Vlookup.

3. Kegiatan pelatihan pengelolaan konten media sosial dan website membahas pembuatan konten yang informatif dan menarik. Hasil pelatihan berupa konten website yang bisa diakses di halaman resmi website Desa Sumerta Kelod.

4. Dari hasil survey pretest dan postest pelatihan Microsoft Word dan excel didapat peningkatan rata-rata jumlah peserta yang bisa dari $43,5 \%$ menjadi $85,8 \%$ dan penurunan yang tidak bisa dari $56,5 \%$ menjadi $14,2 \%$.

\section{UCAPAN TERIMA KASIH}

Terima kasih kepada ITB STIKOM Bali sebagai lembaga yang memberikan dukungan pendanaan sehingga kegiatan ini berlangsung dengan baik. Terima kasih juga kepada Perangkat Desa Sumerta Kelod yang sudah menjadi mitra yang baik dan selalu antusias dengan menyediakan tempat sosialisasi maupun pelatihan, serta kepada seluruh rekan-rekan yang membantu selama kegiatan ini berlangsung.

\section{DAFTAR PUSTAKA}

Anonim, 2017. Kecamatan Denpasar Timur Dalam Angka 2017. Badan Pusat Statistik Kota Denpasar, Denpasar.

Haryoko, Wicaksono, F., 2018. Pelatihan Aplikasi Microsoft Office Dan Desain Grafis Di Kb Minhajul Karoomah. In: Prosiding Seminar Hasil Pengabdian Masyarakat: Implementasi Teknologi Tepat Guna Kepada Masyarakat. Lembaga Pengabdian Masyarakat Universitas Amikom Yogyakarta, pp. 151-156.

Hermansyah, I., Rahman, R., Suherman, M., 2018. Pengaruh Akuntabilitas dan Transparansi Terhadap Kualitas Pelayanan Publik (Survei Dinas Daerah Kota Tasikmalaya). J. Akunt. 13, 21-29.

Munandar, H., Suherman, M., 2016. Aktivitas Komunikasi Pemerintahan Ridwan Kamil di Media Sosial. Pros. Hub. Masy. 423-430.

Niati, A., Soelistiyono, A., Ariefiantoro, T., $2019 . \quad$ Pengembangan Kemampuan Sumber Daya Manusia melalui Pelatihan Komputer Microsoft Office Excel untuk Meningkatkan Kinerja Perangkat Desa Mranggen. E-DIMASJurnal Pengabdi. Kpd. Masy. 10, 105-110.

Rahadi, D.R., 2017. Perilaku pengguna dan informasi HOAX di Media 
Sosial. J. Manaj. dan Kewirausahaan $5,58-70$.

Sormin, M.A., Sahara, N., Agustina, L., 2018. Pelatihan Pemanfaatan

Perangkat Lunak (Microsoft Office Word, Excel, Power Point) Dalam

Kinerja Pengolahan Data Di

Pemerintahan Desa Bagi Kepala Desa

Se-Kecamatan Batang Angkola.
MARTABEJurnal Pengabdi. Masy. 1, 78-82.

Suryadharma, B., Susanto, T.D., 2017. Faktor Penerimaan Media Sosial Instansi Pemerintah di Indonesia. INTEGERJournal Inf. Technol. 2, 110 . 